\title{
Kombinowanie:
}

\section{Agency, Informality, and the Poetics of Self in Highland Poland}

Note on Contributor:

Nicolette Makovicky is Lecturer in Russian and East European Studies, University of Oxford, and has published on themes including labour, ethics, informal economy, and entrepreneurialism in Slovakia and Poland. She is the editor of Neoliberalism, Personhood, Postsocialism: Enterprising Selves in Changing Economies (Ashgate, 2014), and co-editor of Economies of Favour after Socialism (University of Oxford Press, 2016).

Author statement:

I confirm that the submitted manuscript is an original and unpublished text, written by me. This manuscript has been submitted only to the Journal of the Royal Anthropological Institute (JRAI) and is not under review in and has not been submitted to any other journal, book or publishing house, either in whole or in part. It will remain so until a decision on its appropriateness to the JRAI has been made by the editor.

Address/affiliation:

Lecturer in Russian and East European Studies, School of Interdisciplinary Area Studies, University of Oxford, 12 Bevington Road, Oxford OX2 6LH. nicolette.makovicky@area.ox.ac.uk 


\section{Kombinowanie:}

\section{Agency, Informality, and the Poetics of Self in Highland Poland}

This article asks what role local models of agency and subjectivity play in the way informal economic practices are structured and interpreted, and how this influences the ways in which people narrate their behaviour to others. Exploring the use of a common Polish idiom for informal activities - kombinowanie - amongst villagers in the Carpathian Highlands, it argues that, the term acts as a 'master-trope' for local identity, providing villagers with a narrative model for asserting and broadcasting their social agency to peers. Furthermore, it shows how in this particular ethnographic context, the re-telling of instances of informal or illegal activity as kombinowanie can be seen as part of a Highlander 'poetics of self', in that each manifestation of the term carries with it a series of implicit socio-historical and normative meanings that relate to notions of 'typical' Górale behaviour. By characterizing kombinowanie as a type of tactics, I open up the term for comparative analysis with other local conceptions of agency which value insubordination.

On a warm November afternoon in 2013, I sat down to lunch with Pawel, the middle-aged manager of a carpentry business in the Silesian mountain village of Leśna. Over a hearty meal of pork, dumplings, and pickled cabbage, he lamented what he saw as the negative consequences of Poland's over-regulated business environment. Excessive government control, Paweł told me, was not only obstructing business, but meant that running a successful enterprise required a degree of kombinowanie. A common Polish idiom, kombinowanie can be translated variously as 'to scheme', 'to finagle', or simply 'to sort out'. The term is used to describe both a type of activity - an ad hoc employment of practical knowledge to deal with any number of everyday problems - and an 
entrepreneurial mentality that seeks opportunities for accessing income, employment, and education through unconventional means. However, given that kombinowanie can and does often 'involve illegal activity, or more commonly, activities whose legality is ambiguous' (Galbraith 2003:6), I thought it was a rather curious way for Pawel to be describing his business practices to a visiting anthropologist. Furthermore, the literature I had consulted before leaving for the field had informed me that the term covered such practices as petty bribery and nepotism, generally understood to be unfortunate hold-overs from Poland's communist past (Barcikowska 2004, Dunn 2004). Pawel, however, denied that kombinowanie, and the practices it encompassed, were a product of state-socialism: 'No', he told me, 'it's our word, it's an old word. Socialism didn't solve our problems, certainly not our economic problems, and capitalism hasn't solved our problems either'.

Both native and foreign scholars of Polish society have generally treated kombinowanie as part of the socialist-era informal (or 'grey') economy (Pawlik 1992, Wedel 1986, Mazurek 2012), or as a term used normatively by Poles to compare the disappointing realities of everyday post-socialist life with an ideal-type 'normality' where functioning market-forces deliver security and prosperity for all (Galbraith 2003, Pine 2007). By describing kombinowanie as a mode of 'solving problems', in contrast, Pawel presented it as a vernacular practice of 'making do' which took place in the cracks between large-scale economies and state projects regardless of their ideological flavour. Indeed, his notion that kombinowanie was 'ours' and an 'old word' suggested that it was a practice local to the area. Probing further, I discovered that this was precisely what Pawel meant: ' $W$ ell, it is simple (prosta sprawa). If a person lived near a town and needed, say a screw, he could buy it and use it. And the Górale, he had nowhere to buy it. He had to make it. Necessity called for him to create it (mykeombinować)'. With this statement, Paweł did two things. Firstly, he cast himself and his fellow villagers as Górale or 'Highlanders'; descendants of hardy peasants and Walachian pastoralists who migrated across the Carpathian mountain range in the early modern period, and settled Poland's southern borderlands 
(see Cooley 2005). Secondly, he took possession of the term kombinowanie itself, presenting it as rooted in the creativity, resourcefulness, and thrift of his ancestors. Indeed, by evoking the mythical figure of the resourceful Highland peasant, Pawel presented the very propensity to engage in kombinowanie itself as the essential character trait of the Górale.

Over the past two decades, scholars of Central and Eastern Europe have demonstrated the ways in which informal economic practices are embedded in the social fabric and moral imaginations of individuals and institutions across the region. They have shown how personal connections act as a major source of foodstuffs, consumer goods, credit, and employment for people across the region (Williams et. al. 2013, Morris and Polese 2013), and how the post-socialist, neo-liberal marketization of social services, healthcare, and education has influenced local moralities of exchange (Morris and Polese 2015, Rivkin-Fish 2005). Together, these studies have argued successfully for the greater inclusion of local ethical frameworks and social conventions into standard models of dual ('formal' and 'informal') economies (Polese 2008, Wanner 2005). Yet, by focusing on matters of moral economy, authors have paid less attention to the way in which informal economic action is entangled with key aspects of personhood and identity. Few, for example, have asked what role local models of agency and subjectivity play in the way such practices are structured and interpreted, and how this influences the ways in which people narrate their behaviour to others. In this case, Pawel's assertion that kombinowanie was 'our word' served not simply to mark out his business practices as 'informal' or unorthodox. Rather, it appeared to act as a rhetorical commonplace through which he explained his behaviour (and that of his fellow villagers) as characteristic of a particular Górale disposition to labour and enterprise. How was it, I wondered, that kombinowanie - a term used all over Poland - had become imbued with local, Highland practice, values, and ideals in this way? And what significance did this have for how Pawel presented himself and his actions to me? 
In this article, I explore the conceptual and ethnographic implications of these questions. In Leśna, I maintain, kombinowanie acts not simply as a descriptive term, but also as a meaningful idiom that renders the actions of individuals socially intelligible within the particular socio-historical context of village life. Consequently, I treat kombinowanie not as a blanket term for informal economic practices, but rather as a 'master-trope' for local agency and identity. Cultural tropes, writes James Fernandez, are 'metaphoric assertions men make about themselves or about others' which 'influence their behaviour' and 'provide images in relation to which the organization of behaviour can take place' (1972: 42). Kombinowanie, I argue, acts as a cultural trope in two ways. Firstly, it links the improvised nature of contemporary livelihood strategies and material practices in the village with local historical traditions of combining subsistence farming with employment, seasonal migration, and petty enterprise. Secondly, it links such everyday informal exchanges and activities of 'making do' with anti-establishment sentiment, allowing villagers to play with conventional Polish stereotypes of the Górale as impudent and independent-minded, but also prone to cunning and subversion. Such stereotypes are alternately called upon as proof of the protagonists authentically Górale nature (as in the case of Paweł's comment above), or deployed as a ruse to conceal semi-legal (or illegal) activities. Thus, the rhetorical use of kombinowanie not only marks out certain actions as clever and 'cunning', but cunning behaviour itself as a specifically Górale characteristic. Indeed, I suggest that the re-telling of instances of informal or illegal activity as kombinowanie can be seen as part of a Highlander 'poetics of self (Herzfeld 1985), in that each manifestation of the term carries with it a series of implicit socio-historical and normative meanings that relate to notions of 'typical' Górale behaviour.

In short, by treating kombinowanie as a rhetorical idiom, as well as an economic practice, I examine what conversations about economic and material practices can tell us about local concepts of 
personhood and action, as well as the local models of power, money, and the state in which they are embedded. As anthropologist Akhil Gupta has argued, popular narratives about corruption and informality not only shape the 'affective relations that ... citizens have with the state', but reveal how people 'construct what state actions are considered legitimate' (2005:5-7). Building on this observation, I explore the ways in which such narratives also give us clue about how people understand, interpret, and present their own social and economic actions (and their limitations) in relation to state structures. As such, I start by re-describing kombinowanie as a particular form of agency, arguing that Poles associate the term not only with economic informality, but with a much wider range of cunning and subversive behaviour. I then move on to examining how kombinowanie figures in both villagers' engagement in the material practices of life, and their relations with state institutions and bureaucratic power, showing how local farmers and businessmen link their enterprising behaviour to the imagined lifeways of a cast of historical, semi- mythological masculine characters: the outlaw, the migrating shepherd, and the outsider peasant. In so doing, I argue, they make reference to and appropriate two otherwise unconnected aspects of Polish selfidentity: the state-socialist (and post-socialist) hardship, and the national romantic of Highland culture as Polish heartland.

\section{Kombinowanie: From Informality to Poetics of Self}

In contemporary Poland, kombinowanie is a commonplace used to describe a bewildering range of activities and (moral) dispositions, from economic and political corruption, to academic plagiarism, to do-it-yourself house refurbishment ${ }^{1}$. Derived from both 'traditions of gift exchange and from

\footnotetext{
${ }^{1}$ For example, a blogger on the website wPoliticyce.pl informs us that the 'Polish government is increasingly willing to fiddle (kombinowac) with legislation in order to improve statistics and performance' (Cybulski 2013), while elsewhere university students explain how they cheat at exams, lamenting that 'studies teach you how to swindle' (studia uczq kombinowania) (Onet 2013). Elsewhere, a blogger wryly celebrates the return of 'Kaptain Kombinowac - his DIY disaster prone landlord (Stoke 2010).
} 
the experience of a shortage economy' (Dunn 2004:119), it often involves the use of znajomości ('connections') who can 'arrange things' (zalatwic sprawy) by jumping through bureaucratic hoops. It may require the concealment of employment, income, and ownership from the authorities, or even instances of nepotism, low-level corruption, and pilfering from public resources. Kombinowanie thus belongs to a genre of practices that creatively interpret - or completely circumvent - official avenues to income, employment, and welfare often given the shorthand 'economies of favours' (Ledeneva 1998). Historically, the term was used to describe the survival strategies adopted by Holocaust victims and the wider Polish population during the Second World War (Kusiak 2012, Materka 2018). Later it became associated with the 'different forms of self-help, as well as more or less legal forms of entrepreneurship' that 'enabled people to cope with the omnipresent shortages' of post-War, communist Poland (Mazurek 2012:298-9). Indeed, in the English language literature, kombinowanie has variously been translated as clientelism (Hann 1985), or equated with political patronage (Kennedy and Bialecki 1989), and participation in the socialist-era 'second' or ‘grey’ economy (Pawlik 1992, Wedel 1986).

As a result of this history, kombinowanie is a term burdened with a certain degree of moral ambivalence, as well as national sentiment. Describing it as an unfortunate adaptation to the sociopolitical perversities of the socialist state, Anna Barcikowska (2004:1) has argued that kombinowanie was the characteristic tool of 'Soviet Man' - an 'unprincipled survivor, publicly conformist and privately selfish'. Likewise, Małgorzata Mazurek concludes that it arose due to the widespread "family-oriented egoism or "amoral familism"” of the population at the time (2012: 306). Others, however, challenge such singularly negative views of kombinowanie. Edyta Materka suggests that while '(k)ombinacja expresses Poles' poor confidence in formal economic and political institutions', it does so precisely because 'getting round the system' has been a more effective strategy for preserving both the family unit and the nation in the past (2018:??). Polish sociologist Joana Kusiak 
goes further, claiming that coming up with 'ingenious, creative, often semi-legal or illegal solutions' has 'since feudal times' been 'considered a skill to be proud of, as it allows the underprivileged to access otherwise inaccessible resources and trick their oppressor' (2010:279). Presenting kombinowanie as an ahistorical form of socio-political subversion, these authors illustrate the degree to which the term is imbued with enduring Polish self-stereotypes: the first constructs Poles as deeply committed to the national idea, but exhibiting a deep-rooted resistance toward any kind of centralized authority; and the second represents them as capable of social solidarity in a crisis, but petty, selfish, and inward-looking behaviour at other times (Galbraith 1997:122-3).

As such, there appear to be interesting questions to be asked not just about the place of kombinowanie in local (and national) moral economies, but also about how the concept forms part of Polish constructions of identity and personhood. Indeed, examining kombinowanie's sisterconcept znajomości, Elizabeth Dunn (2004) has already suggested that Poles' frequent use of personal connections is related to particular aspects of their social imaginary, rather than simply being a question of economic or political necessity. Borrowing Marilyn Strathern's (1988) notions of the 'dividual', she argues that the use of znajomości relies on a particular understanding of people as 'the plural and composite sites ongoing exchange relationships' (ibid.:126). This belief that individuals hold power and resources by virtue of their relationships with others, Dunn argues, has consequences for the way in which people become social actors: they act 'upon the world by acting upon others... using personal connections to manoeuvre around immobile obstacles' (ibid.). Contrary to authors such as Barcikowska, then, Dunn sees the use of znajomości and kombinowanie not as the expression of communist-era social atomization and 'institutionalised selfishness', but rather as the mark of a completely socialized individual. Indeed, by focusing her analysis on models of personhood and social action, she grasps at something fundamental which has been obscured by scholars' tendency to treat these concepts primarily as the outcome of the political economy of 
socialism: namely, the possibility that kombinowanie (and znajomości) is a term which is used to describe a particular form of agency, rather than a defined set of (informal or illegal) practices.

While Dunn never explicitly commits herself to such a re-description of znajomości, I aim to demonstrate the ways in which such a re-conceptualization can be theoretically profitable. As such, I regard kombinowanie as a term used to describe action which is imagined as happening despite, around, or even directly against power, rather than merely as behaviour driven by material hardship ('survival strategies') or the constraints imposed by dysfunctional formal institutions ('informality'). Thus, while such action may take the form of economic practice, it is its anti-establishment nature - rather than its economic roots or goals - which defines it as kombinowanie. Consequently, I suggest that kombinowanie can be understood as an example of what Michel de Certeau (1984) has called 'tactics': practices of 'making do' or 'ways of operating' which are rooted in the historical sedimentation of habit in the body, and which make use of the gaps between monitored, prescribed behaviour and the ambiguities and unpredictability of everyday life to reclaim the spaces and places of power. De Certeau illustrates his concept using the French expression la perruque, or 'the wig': the practice of using the time which belongs to one's employer for one's own activities. Such behaviour would be instantly recognizable to any Pole as a type of kombinowanie.

By characterizing kombinowanie as a type of tactics, I open up the term for comparative analysis with other local conceptions of agency which value insubordination. Documenting the existence of terms for such 'everyday cunning' - from the la furbizia of the Neapolitan underclass (Belmonte 1979) to the combinazione of Italian peasants (Holmes 1989) - anthropologists of marginal and rural populations across Europe have shown how the celebration of unorthodox behaviour is often characteristic of communities chafing against the changes and prescriptions imposed by a 
modernizing state. Michael Herzfeld's $(1985,2004)$ ethnographies of Crete provide a particularly instructive parallel. Noting that a subversive attitude to state power is part of the Greek selfstereotype, he observes that insubordination is not only expected, but is routinized as part of bureaucratic procedure. However, while insubordinate behaviour is considered a national characteristic, specific acts of resistance nevertheless rely on the performance of much more localized tropes of gender and social status. Thus, Herzfeld describes how the training of artisans on the island of Crete breeds insolence towards authority, as well as an attitude of koutoponiria (dumb cunning) designed to 'get away with' acts of insubordination (2004: 47-52). The connection between their 'craft' and their 'craftiness', Herzfeld writes, leads to their celebration as the epitome of the Greek spirit of freedom. Similarly, Cretan shepherds reproduce local notions of masculinity through displays of poniria - cunning and insubordinate actions such as animal theft and physical altercations (1985:25-33). Herzfeld teaches us, in short, that resistance must be publicly witnessed and acknowledged as identity or attitude, and that it is enacted through the performance of local idioms that have their own history. He calls this performance a 'poetics of self' (ibid.).

In the case of the Polish Highlanders, these tropes are shaped by their historical role as a Polish national icon. From the mid-19 $9^{\text {th }}$ century, national romantic elites elevated the Carpathian borderlands into a Polish national 'poetic space' (Smith 1984). This discovery of the Highlands was accompanied by the mythologization of the local Górale population as the proud, 'freedomloving son[s] of the mountains' (Kroh 1999:133). In the romantic imagination, Highlanders had remained untouched by the powers of (foreign) feudal lords and the repressive culture of the aspirational bourgeoisie, and lived a life 'very close to nature, scattered among the mountains, independent to the point of folly, brave and impudent' (Lorentowicz in Manouelian 2000:399). This picture of the Górale as a figure of heroic independence, however, has since been challenged by other, less attractive, stereotypes of Górale behaviour, including the widespread perception that 
Highlanders engage in excessive drinking, womanizing, and violence. Frances Pine has described how the Gorale propensity for enterprise and trade, in particular, has led the cultivation of a popular image of Highlanders as 'uncannily 'knowing' in their pursuit of a good deal' (2002:7). As she notes, this is an image of ambivalence which Highlanders enjoy toying with, often 'beginning stories and jokes with the phrase "There was once a poor stupid Górale - just like me", but then proceeding to portray themselves as 'tricksters, dealers, and social alchemists, borrowing and appropriating what they wanted and taking it stealthily back to their community' (1997:65).

Such narratives of trickery help locals present themselves and other Górale as 'renegades' - fiercely independent, with an instrumental relationship to centralized power and the rule of law. As in the case of Herzfeld's artisans and shepherds, these stories play a key role in Highlanders' performance of their role as icons of Polish identity, while simultaneously subverting the (bourgeois) ideals upon which this status is built. And yet, while the Górale inhabitants of Leśna may share much in common with Herzfeld's Cretans - from their geographically peripheral position and their reputation for cunning insubordination, to a flair for flamboyant performances of local identity it would be a mistake to simply equate the Polish concept of kombinowanie with the Greek notion of poniria. While both terms signify a type of insubordination which serves to demonstrate the moral superiority of locals vis-à-vis the representatives of (state) power, kombinowanie is enacted through the demonstration of a particular type of practical intelligence. As such, the closest ethnographic analogy to kombinowanie may not be poniria, but rather the concept of débrouillardise used by the Auvergnant peasantry, described by Deborah Reed-Danahay as an 'honest form of resourcefulness and social manipulation' (1993:224). Like kombinowanie, débrouillardise is related to the more widely used French idiom for 'getting around' bureaucracy, Le Système D (for debroniller), but retains a particular connection to local identity. Débromillardise, writes Reed-Danahay, constitutes a form of 'everyday resistance', but should not be understood as a 'hidden transcript' 
(Scott 1990) underlying public compliance. Rather than simply being a 'reaction (or resistance to) dominance' (1993:223), she argues, it constitutes a type of 'play' with meaning that both accommodates and resists structures of governance.

In the remainder of this article I examine three different contexts and narratives in which kombinowanie - as this sort of 'playful' cunning - was employed by villagers in Leśna. Taking my inspiration from Fernandez' suggestion that social interaction can be understood as a 'play of tropes' (1986), I treat each manifestation of the term as carrying a series of implicit socio-historical and normative meanings that relate to higher order notions of 'typical' Górale behaviour. I start by examining the socialist-era domestic production of tractors, illustrating how villagers associate kombinowanie with a type of vernacular creativity and practical knowledge born of the physical and economic hardships of Highland life. By analysing kombinowanie as a form of bricolage, I suggest not only that in Leśna 'making' and 'making do' are connected and contingent upon one another, but that bricolage itself constitutes a particular 'way of operating' (de Certau 1984:xiv) in relation to the world outside the local community in general - and the structures of official state power in particular. This leads me to consider how and why entrepreneurs in contemporary Leśna deploy kombinowanie against public institutions and their representatives. By engaging in such behaviour, I argue, they not only 'play' the system, but consider themselves to be preying on the apparent ignorance of its agents - agents who they consider equally, if not more, prone to engage in corruption and manipulation. Finally, I show how the selective appropriation of the long-standing mythology of the 'freedom-loving Górale' and its key figures (the peasant, the shepherd, and the brigand) by locals imbues otherwise quite ordinary instances of kombinowanie with particular significance, turning the use of unofficial channels to achieve one's goals into a demonstration of the autonomous spirit characteristic of Highland peasants. 


\section{Kombinowanie as 'bricolage'}

Situated high in Carpathian Mountains of Southern Silesia, Leśna was founded in 1712, and fell under Habsburg administration after the partition of Poland as part of the Dukedom of Cieszyn Silesia. Before Habsburg policies of enclosure ensured the elimination of the village commons and pasture in the late 19th century, the inhabitants practiced a form of transhumant pastoralism and subsistence farming, as well as working as loggers. Despite putting more land under the plough, enclosure went little was to preventing the gradual fragmentation of arable land under the pressures of population growth and the Austrian law of partible inheritance. With the typical plot reduced to 1-3 acres, families employed not only the classic tools of the peasant-worker (short- or longterm emigration and/or the take-up of wage labour), but used the domestic sphere as a base from which to engage in legal or illegal private enterprise in the form of trade, petty commodity production, and services for the ever-growing number of tourists visiting the area. From the last quarter of the 19th century, a large proportion of young men and women left the area to seek their fortunes in North America. Indeed, emigration remained a popular strategy up to (and even during) the socialist era, when industrialization and the policy of full employment led the majority of villagers of both sexes to take up wage labour in manufacturing, mining, and the burgeoning tourism industry alongside the cultivation of their plots. Despite the best efforts of the Communist leadership to consolidate and socialize the agricultural sector (Buchowski 2009), most families in Leśna not only clung to their land, but continued to view the farming household as the base for other lucrative activities: making and trade crochet lace, providing room and board for holidaying urbanites, and smuggling consumer goods across the border with Czechoslovakia (Kieres 2010, 2012).

After the demise of Communist rule in 1989 and the collapse of the structures of the socialist-era command economy, it was these practices of informal domestic production and trade that supplied 
avenues for enterprise and employment in the village. A large number of local businesses are based in a commercialization of local cultural heritage, including several construction companies specialized in building neo-traditional, 'Górale-style’ log houses and inns serving traditional cuisine. With European Union subsidies, pastoralism has returned to the area and traditional cheesemaking now competes for the tourists' attention with a plethora of souvenirs shops peddling local crafts. Once the staple of every household's economy, however, subsistence farming is now on the retreat. Today, families in the village increasingly choose to lease their land to several, larger commercial farmers, or sell off their land to relatives, fellow villagers, or even outsiders as building plots for new homes. The 70 year-old Adam, the father of my landlord Piotr, was one of the few villagers to stubbornly continue to run a family smallholding after retiring from the local sawmill. The small-holding - some two acres and a wooden cottage at the southern periphery of the village - had been his childhood home, and Adam continued to work the land and raise poultry in the courtyard. He also kept two cows. Yet, as an outsider, I found the most surprising aspect of Adam's farming to be his tractor: he had built it with the help of a neighbour, purchasing and pilfering the materials from a variety of sources, including scrapped vehicles from his former workplace. Painted dark green, he described the machine as a kombinacja: 'The engine is from a Mercedes [truck]', he told me proudly, patting the rusting bonnet made of roughly riveted together sheets of metal, and 'the wheels are from a Polski Fiat'.

[Insert Fig. 1.] A homemade tractor in Leśna

The outcome of a creative re-appropriation of used parts, Adam's kombinacja of a tractor was a work of assemblage, or bricolage. Here, kombinowanie took an almost literal meaning, referring as much to the creative combining of parts and materials, as to the informal nature of their sourcing 
and construction. In building his own tractor, he took on the role of Levi-Strauss's bricoleur; a jackof-all trades 'who works with his hands and uses devious means compared to those of a craftsman' to make, repair, and reconstruct the material world (1966:17). (fig 1,2). According to Adam, his tractor was a necessary outcome of the difficulty of farming the local environment: industrially made tractors were too large and too heavy for the local mountain terrain, he told me, and would not have been able to handle the steep, winding roads and hillsides of the village. Homemade tractors, however, were also a product of the Communist Party's discriminative policies against independent smallholders until the early 1980s. Although the Polish state abandoned attempts at the collectivization of agriculture in 1956, it continued to discriminate against smallholders by prioritizing cooperative producers' access to the equipment and materials needed for modern agricultural production. Until 1972, for example, industrially manufactured 'Ursus' tractors were allotted only to those producers who turned over a set minimum of their produce to the state at the (low) official purchase prices, effectively excluding all but the large State Farms of the lowlands (Nagengast 1982). Attempting to circumvent these rules was possible but costly: the price of an 'Ursus' tractor was 40,000 zlotys and bribing a clerk to allot one cost 60,000 zlotys (Skapski 2007). As Krzysztof Gorlach (1991) has argued, this policy led to the creation of a 'psychosis of possession' in which farmers strove to be self-sufficient in mechanical equipment, as well as labour and produce. As a result, the tractor became symbolic of a 'feeling of social agency' achieved through asserting a limited independence from the authorities (1991:10-12).

As Frances Pine (1996) has argued, such symbolic manifestations of self-sufficiency were particularly valued amongst the Highland peasantry. Ideologically construed as the crux of socialist citizenship and progressive industrial modernism, work in the state sector was presented by Highland villagers as a necessary evil which gave access to welfare benefits and materials for lucrative semi-or illegal private enterprise (2002). Thus, despite villagers' increasing dependence 
on the state sector for wages, services, and consumer goods during the second half of the $20^{\text {th }}$ century, it was the agricultural household which remained 'the core of social and economic identity, and a metaphor for kinship' (1996:443). Homemade tractors like Adam's, then, could be seen as both a pragmatic solution to the lack of adequate agricultural machinery, as well as a form of quiet rebellion against a state employing scarcity as tool of reform. Furthermore, constructed and used almost exclusively by men, tractors constituted a particularly masculine symbol of social agency (see Brandth 1995, Saugeres 2002). Given that Leśna's male population had access to several avenues of stable employment, including exceptionally well-paid and ideologically celebrated shiftwork in the Silesian coal mines, the choice of men such as Adam to dedicate time and resources to agricultural work reflected disinterest in, or perhaps distrust of, the paternalism of the socialist state. Indeed, contemporary Polish artist Lukasz Skapski (2007) describes the unofficial (domestic) production of tractors by Highland peasants as an 'anti-corporate activity': at once utilitarian and a mark of creative individuality, it broke the monopoly of state production and exposed the failures of the socialist modernist project to take account of the needs of the individual citizen.

[Insert Fig. 2] Driving home down a steep hill in a homemade tractor.

Pitching these tractors as a symbol of the incompetence of state power in the face of vernacular practice, Skapski recasts vernacular bricolage as a politically subversive practice. And yet, as Pine notes, this vision of the Highlands as a 'Chayanovian backwater' holding out against the 'Taylorist planned production and industrial rationality' of the socialist project oversimplifies the relationship between the peasant smallholding and the socialist state (2007:188). Rather, by finding ways to hold on to and even expand their agricultural activities through income, remittances, and enterprise, Górale smallholders 'maintained a shifting power relationship with the state, in 
response to changes in the broader political economy' and local economy enjoyed 'various different modes of articulation with local, national and international/global economies' (1996:443). As worker-peasants living barely sixty miles from Poland's industrial heartland, the inhabitants of Leśna took advantage of the socio-economic and technological advances of socialist modernity while making use of the gaps and margins of the state system to maintain control over their family assets. Thus, the domestic production of agricultural machinery should be seen less a wholesale rejection of socialism's teleological narrative of industrial progress, than an attempt by locals to mechanize (and modernize) local agriculture without this resulting in their own proletarization. As we shall see below, such instrumental attitudes to centralized authority continue to permeate the actions and choices of villagers today, together with a fidelity to the historical tradition of combining small-holding with migration, employment, and petty-trade in the village. As such, kombinowanie as material practice is mirrored by a local tradition of kombinowanie as 'making do' or 'getting by' which often involves not simply the transgression of the law, but also the open mockery of its official representatives.

\section{Kombinowanie as 'a way of operating'}

In the early 1990s, the end of Communist rule in Poland 'ushered in a new era of what the Poles called biænes - mom-and-pop service industries and traders hawking everything from bananas to computers' (Wedel 1998:165). In the weeks and months following the collapse of Communist Party rule, an explosion of small businesses appeared across the country, exploiting the abundance of commercial niches and consumer demands which had been neglected by the productioncentred planned economy. Swept up in this tide of entrepreneurial activity, one young man in Leśna started a small business selling the local, 'folky' crochet lace. The first male villager to enter a trade which had previously been the exclusive preserve of the village's female artisans, Roman started out as a travelling salesman, peddling lace at markets and fairs across the country. Over the 
next decade, he built a successful wholesale business which now supplies more than 60 retail outlets. Despite his success, however, Roman was troubled by the lack of fit between the particular nature of handicraft production, and the increasing regulatory demands made of him as an employer: 'I used to have several people employed on a work contract, right? As home workers (chatupnicy). Later, when the rules changed for those women, then everything was done to make sure they had the right to unemployment [benefits], you see? They were employed for a while, as soon as they had earned the minimum, they ran away, and got unemployment benefits. And then they earned a little on the side, right?'. Struggling with low profit margins and increasing competition from other traders in the village, he told me that these days 'unfortunately, one has to scheme' (niestety, no trzeba kombinowac).

In the same way that Pawel spoke of kombinowanie as a kind of vernacular 'problem solving', then, Roman presented the legally questionable aspects of his business as part of a pragmatic strategy for economic survival. Unlike Pawel, however, he did not associate kombinowanie directly with the history or culture of his fellow Highlanders. Instead, Roman blamed the Polish state and its political representatives for his need to scheme. Like many other small-time entrepreneurs in the region, he was convinced that policymakers were more concerned with lining their pockets, than with ensuring the well-being of their constituents (see Malewska-Szalygin 2008). Rising business rates and payroll taxes, Roman told me, discouraged traders and artisans from declaring their profits, leaving the development of local enterprise to happen 'in the wild' (na driko): 'Instead of promoting small companies and folk artists', he complained, politicians designed legislation which only supported 'big businesses and their own interests'. Portraying himself and his employees as the victims of a corrupt and incompetent government, he maintained that his own commercial practices bore the mark of a socially responsible business-owner. By hiring artisans just long enough to ensure their eligibility for unemployment benefits (and continuing to employ them informally thereafter); he enabled them to maximize their income by combining their meagre salaries with social wages. 
While this practice was fraudulent, it was also mutually beneficial for all parties involved: it secured the profitability of Roman's enterprise by keeping overheads low, and it ensured the livelihoods of artisans who would have been hard pressed to find (legal) employment elsewhere. In short, rather than a corrupt practice, Roman presented kombinowanie as a collaborative exercise which worked to support the entire community.

Roman was fairly typical of Leśna's employers in his use of unregistered labour, as were his employees in their willingness to work cash-in-hand while taking advantage of social benefits (see Makovicky 2017). Yet, while he blamed the perversities of contemporary Polish politics for this situation, ethnographies have shown that Highlanders have long adopted strategies of exploiting multiple sources of income and treating the state as a socially distant supplier of benefits. During state-socialism, employment in the state sector was a pre-requisite for getting access to basic social benefits and service, such as medical and dental care, childcare, and a pension. Running a family smallholding did not render one eligible for support. Neither, of course, did involvement in the 'second' economy. And yet, as Frances Pine (2007:8) points out, it was precisely activities which belonged to this final category which 'allowed money to grow', fuelling the expansion of household wealth and the aspirations of its individual members. Thus, while regular employment had ensured a modest wage and access to public services, Highlanders often funded major expenses such as housebuilding or weddings through activities such as smuggling or bootlegging vodka, overextending their licenses for the private production, or trading in lace, sheepskins, wood carvings (Pine 1987:55). This propensity to use the gaps and margins of the state-socialist system to engage in (semi- or illegal) enterprise clashed with the official condemnation of trade and private enterprise as 'speculation', severely testing relations between villagers and state authorities. The mutual distrust which resulted continues to mark the attitude of the Górale towards state policies and 
institutions today, leading villagers to treat their official representatives with a great degree of instrumentalism (Malewska-Szalygin 2006, Pine 2007).

Such instrumentalism was expressed by Lukasz, another lace trader operating in Leśna. Almost two decades Roman's junior, Lukasz joined the industry in the mid-2000s, following the commercial success of a new artisanal product: handmade, lace lingerie. Sensing a commercial opportunity, he opted to establish an online shop retailing lace via a digital interface, rather than working as a wholesale supplier or retailer with commercial premises. On one part of his website, discreetly photographed bottoms and chests showed off crocheted lingerie for sale, while an alternate route from the start page lead to a more traditional set of images of elderly ladies in 'folk' costume making lace tablecloths and doilies. Despite apparently having a very different business model from that used by Roman, however, Lukasz voiced the same frustrations about the lack of policies supporting small-scale entrepreneurs: 'The government does not give a damn about us (rzad ma nas w nosie - literally 'the government has us in the nose')! So if you want to run a business these days, you simply have to know how to kombinować (prosto trzeba umiec kombinować)'. Indeed, on closer inspection, his kombinowanie mirrored that of his more established colleague perfectly. Like Roman, Lukasz was unable to design or make lace himself, and relied on maternal kin and their female friends to advise him on the price and manufacture of his products. He paid them cash-in-hand for their labour in order to avoid the burden of payroll taxes. With a mischievous smile, Lukasz told me that he had solved the problem of how to explain his supply by registered himself as self-employed artisan: 'Officially, I make the lace. Because you have to explain it to the authorities in some fashion. And they are always surprised'. 
In contrast to Roman, then, Lukasz was decidedly unapologetic about his kombinowanie. Indeed, he took evident pleasure in telling me about his insubordinate behaviour, constructing a picaresque narrative which cast him as a slightly comical hero who managed to subvert the powers that be with an unlikely story of craftsmanship. His claim to have crocheted hundreds of sets of women's underwear and doilies - a story which ran counter to generally accepted norms of gendered behaviour (and was therefore 'obviously' untrue) - made him appear to be either a bold maverick, unafraid of overturning conservative norms, or simply laughably effeminate. Thus, while both men justified their kombinowanie with the claim that Polish politicians had skewed post-socialist market reforms in favour of urban elites, Lukasz injected a degree of humour into his narrative, turning it into a trickster tale which illustrated the fallibility of state powers in the face of the cunning of the ordinary citizen. In his tale of petty subversion, then, kombinowanie emerged not simply as a strategy for employment and enterprise, but as a distinct 'way of operating' (de Certeau 1984) in the face of central government. Indeed, by revealing to me the intimacies of his business practices, Lukasz not only intimated that he was exploiting the loopholes in the system, but cast himself as a trickster exploiting the naiveté (or stupidity) of government bureaucrats who were either too risk-adverse, or simply too lazy, to check his unusual claims. As such, he only made a powerful statement about his attitude towards bureaucratic power, but presented his kombinowanie as evidence of a particular type of practical intelligence which operated through the strategic manipulation of local knowledge and cultural stereotypes, as well as personal connections and physical materials.

As we shall see below, Lukasz was not the only villager to portray himself as a trickster adept at subverting authority. Rather, I was often treated to picaresque tales of kombinowanie in which symbols of government were roundly disparaged, and treated as naïve or unprepared outsiders who were defeated by the common-sense wisdom of the ordinary Highland peasant. Like Lukasz, locals seemed to derive a great deal of moral satisfaction from demonstrating their ability to 
circumvent regulations and escape the scrutiny of the authorities. As such, however, their picaresque tales of trickery appeared to be less about the wish to resist or overturn power structures, but rather a particular idiom through which they sought to assert and broadcast their social agency to their peers (or visiting anthropologists). Ellen Basso (1985:54) has argued that trickster tales reflect not only the social concerns and interests of a community, but also local perceptions of agency and self-identity. Investigating such stories, she contends, allows us to 'consider how idea of subjectivity (or the "self') are realized in and through discourse' (ibid.). Following Basso, I want to conclude this article by arguing that tales of kombinowanie provided villagers in Leśna with a narrative model for recounting their actions and motivations. Indeed, I show how such stories became a potent rhetorical tool for the performance of Górale identity by linking instances of kombinowanie to the imagined lifeways of a cast of historical, semi- mythological (masculine) characters: the outlaw, the migrating shepherd, and the outsider peasant. By making implicit comparisons between their own behaviour, and that of their Highland ancestors, they recalled romanticized notions of Highland 'freedom' which tested the geographical and legal boundaries of the Polish nation-state.

\section{Kombinowanie as a 'poetics of self'}

Mid-way through my first meeting with Leśna’s head shepherd (baca), Andrzej, abruptly broke off our conversation: 'What do you mean 'Sir"?', he admonished me, T always tell everyone, that you should not make a lord out of a Góral (nie zrobic pana z,górala). The gentlemen are down in the cities'. Wishing to be polite, I had addressed him using the conventional Polish Pan (Mister, or Sir), instead of the more informal ty, but he cringed visibly and asked me to address him by name, or using the local term ujсu ('uncle'). Today, Andrzej manages a herd of 1200 sheep, and makes a good living producing traditional fresh, fermented and/or smoked Highland cheeses for the Polish market, and exporting spring lambs to Italy. Like many other men in Leśna, however, he spent his bachelor years abroad, 
working in the construction business in Ireland. Grinning widely, he treated me to vivid descriptions of the kinds of kombinowanie which came about when young men shared accommodation far from the eyes and ears of their girlfriends and parents. Several of his stories focused on their efforts to transport large amounts of home-made foodstuffs and liquors to Dublin for Polish-style celebrations with friends. Ignoring the disapproving looks of his wife, Andrzej chuckled as he recounted how they would smuggle in larger than legal amounts of alcohol by emptying mineral water bottles, filling them with vodka, and then strolling through customs feigning innocence. Occasionally, the surreptitious import of these foodstuffs would meet with an accident, as when a large duffel-bag filled to the hilt with sausages split at the seams and ejected its contents across the luggage belt of Dublin Airport, leaving Andrzej scrambling on all fours chasing sausages across the terminal floor.

Presenting himself as simultaneously a heroic migrant and a rural buffoon, Andrzej's story of youthful kombinowanie marked him out with the defining characteristic of the trickster; namely the ability to live interstitially: 'outside or between the boundaries of dominant groups' (BabcockAbrahams 1975:150). As it turned out, he not only associated such marginal mobility with personal liberty, but migration itself as the core characteristic of Highland culture. Waxing lyrical over plate of smoked sheep's cheese and a bottle of homemade raspberry brandy, he told me that ' $a$ Góral isn't a person connected to a certain place, he is person on the road. Because the shepherd is a person always in motion. The most characteristic thing about a Góral is his need for freedom'. The Highlanders, he explained to me, were not simply 'inhabitants of the mountains', but those people who 'refer to pastoral culture' and 'build their identity on the base and source of a way of life that was being created across the Carpathians'. In Andrzej's eyes, not just fellow Górale groups in the Czech and Slovak borderlands, but also Ukranian Lemkos and Romanian Hutsul groups were his cultural brethren, all the product of an ancient historical migration of shepherds and their flocks across the mountaintop pastures of the 
Carpathians. In this light, the tale of the sausage incident at Dublin airport began to take on the flavour of an etiological narrative: in Andrzej's trickster tale, the Górale shepherd and the migrant - both socially marginal figures moving between territories - became twinned through their affinity with the mythical, 'freedom-loving' Górale, suggesting their (and by extension his) ability to rise above the normal constraints of social status and political governance.

[Insert Fig. 3] A jubas working for Andrzej.

Michael Herzfeld (1985) has argued that the production of such meaningful affinities lies at the heart of the enactment of subjective identity. 'Any performance of the self, he writes, is enacted through an allusion to 'ideological propositions and historical antecedents', becoming a 'metonymical encapsulation of some more inclusive entity' (1985:10). Consequently, social interaction can be seen to operate through the strategic deployment of stereotypes and 'practical essentialisms', forming a certain 'social poetics' of everyday life (Herzfeld 2004). Punctuated by frequent references to Highland lifeways and traditions, my conversations with Andrzej not only took on a particularly poetic quality, but often appeared to present an opportunity for him to publicly assert a degree of cultural and ideological kinship with his imagined pastoral ancestors. Thus, while Roman and Lukasz blamed their kombinowanie on the corrupt nature of contemporary Polish political elites, Andrzej perceived such subversive behaviour as the legacy of a history of anti-establishment conduct amongst Highlanders: 'Long ago, in the 19 $9^{\text {th }}$ century and before', he told me, 'the Górale managed to convince their masters that renegades (zbójnici) were raiding their pastures. To this day, some people believe it. But it was all made up'. When a sheep went missing, he explained, 'the baca pretended that the brigands had raided them. But actually he was feeding them [the brigands]'. Highland shepherds protected brigands in this way, Andrzej maintained, because they knew that they were not criminals 
at all, but 'sort of political refugees: They had done something and had to hide'. Spinning a narrative about the cunning heroism of shepherds and brigands, in other words, he portrayed the local disdain for (state) authority as part of the innate Górale 'need' for freedom.

Andrzej's request that I not 'make a lord out of a Górale', then, suggested not only that he wanted to maintain a distinction between his Górale self and an urban 'Other', but that he sought quite consciously to portray his actions in terms of local tropes of agency and behaviour. As the village baca, he was responsible for the collective grazing and milking of several hundred sheep owned by members of the local community. During the spring and summer, these sheep ruminated on fallow agricultural plots and patches of meadowland under the watchful eyes of his three employee shepherds (juhasi)(fig.3). Andrzej, meanwhile, managed the commercial side of the business, including the yearly re-negotiation of the terms under which he could lease land and livestock from other villagers. He was also tasked with ensuring that the production and sale of his cheeses complied with complex European trading standards, an onerous task which required much paperwork and an intimate knowledge of the regulations surrounding food hygiene and veterinary health. Drawing on this experience, he consulted key officeholders in the Silesian regional administration on the development of environmental programmes which channel European Union subsidies to local pastoralists. Together, he told me, they had managed to match the needs of local pastoralists to the requirements of the Common Agricultural Policy: 'Well, you see that is the whole problem', he said, '... all countries which have signed the Policy are banned from providing subsidies for livestock. [...] All the money goes through surcharges on agricultural land'. But it is possible for them to pay a subsidy for servicing livestock. And that is the whole trick. It is a sort of kombinajca through which we can divert [the money] into our industry in a legal manner'. 
Referring to the environmental project he had helped to devise as a kombinacja, Andrzej employed the term in the usual way to highlight the fact that it entailed a creative reinterpretation of the rules governing the disbursement of CAP subsidies. And yet, this tale of cunning stood out from other narratives I heard in Leśna in several, crucial ways. First of all, the story hinged not on a material demonstration of Andrzej's practical intelligence, or a comic presentation of his entrepreneurial flair. Rather, it appeared to be part of an elaborate 'poetics of self (Herzfeld 1985) - that is, a performance designed to affirm his authentically Górale nature - delivered alongside picaresque tales about the adventures of errant migrants, crafty brigands, and subversive shepherds. Indeed, Andrzej's ideas about traditional Highland customs and lifeways seemed to be lifted from local folklore and 19th century national romantic literature, rather than being grounded in his everyday experience. Secondly, in this instance the kombinowanie was done in collusion with the regional authorities, rather than at their expense. Despite his frequent recourse to a semi-mythologized version of local history, and stories of his own youthful insubordination, Andrzej was clearly a man who maintained (and profited from) intimate ties with local political power. In a village where one woman proudly told me that she had grown up 'shovelling muck' out of the family stables, cultivating such a close relationship with officialdom left him open to criticism. By framing his consultancy work in terms of kombinowanie, however, allowed him to re-describe his collaboration with the regional authorities as anti-establishment behaviour by evoking the European Union as the higher-order authority which had fallen victim to their scheme. Employing the trope of kombinowanie, in other words, Andrzej sought to render his actions socially intelligible within the socio-historical context of village life.

\section{Conclusions}


Students of Polish society have typically considered kombinowanie as belonging to a wider set of informal practices found across the former Soviet Bloc, theorising it as a type of fraudulent behaviour with roots in the political economy of socialism. In this article, I have eschewed generic models of (post)socialist informal economic practices to explain instances of kombinowanie in Leśna. Instead, I have argued that the term operated as a rhetorical commonplace used by villagers to describe various material, economic and social practices which they felt in some way to resisted the regulation, control and surveillance of the nation-state - from the material assemblages made in times of scarcity (Adam's tractor), to informal employment and tax evasion (Roman's and Lukasz's payment of artisans cash-in-hand), and even the formulation of new economic projects which distorted the framework of European legislation (Andrzej's environmental project). Furthermore, I showed how kombinowanie acted as a 'master-trope' for local agency and identity, providing villagers with a narrative model for recounting their actions, and for asserting and broadcast their social agency to peers (and visitors). As such, I argue, it formed a crucial part of a Highlander 'poetics of self, enabling villagers to re-cast their actions in terms of local notions of ‘typical' Górale traits.

My broader aim has been to illustrate the theoretical potential of alternative approaches to studying post-socialist informal economies. In particular, I have sought to challenge the conventional anthropological focus on the systemic factors underlying such exchanges, or the moral economies in which they are embedded, by questioning how economic action is entangled with local notions of identity, subjectivity, and vernacular models of authority. In this case, two observations stand out. Firstly, kombinowanie appeared to be a trope particularly associated with the local performance of masculine identity: while women in the village did employ the term everyday speech (see Makovicky 2017), it was only men who used kombinowanie to reflect upon their behaviour in conversations and interviews with me. Furthermore, the figures of the Highland peasant, the 
shepherd, and the renegade to which they alluded in our conversations were also all male. Secondly, male villager's use of kombinowanie to signal the 'clever' or 'cunning' nature of their behaviour appeared to be inversely related to both their engagement in the material practices of life, and their relations with state institutions and bureaucratic power. While Adam did not project the building of his tractor as a politically subversive practice, Paweł, Roman, and Lukasz all used the term to highlight the maverick nature of their business practices. And finally - in what appeared to be a bid to project himself as the living embodiment of the ancient Highland shepherds who had once colonized the Carpathians - Andrzej attempted to characterize his highly responsible, but also largely managerial role in the heroic terms of his ancestors. In short, when labelling their actions as kombinowanie, these men were not simply describing their need to overcome existing material and bureaucratic obstacles. Rather, they appeared to be offering evidence of their engagement in the subversive and insubordinate behaviour they regarded as central to the performance of local, male identity.

\section{Acknowledgements}

I am thankful for the insightful comments made by Michael Carrithers, David Henig, and Zuzana Burikova-Sekerakova in the course of the writing of this article, as well as the three anonymous reviewers commissioned by the JRAI. The fieldwork upon which it is based was funded by an AHRC Early Career Fellowship grant (AH/I001891/1).

\section{References}

Babcock-Abrahams, B. 1975. "A Tolerated Margin of Mess": The Trickster and His Tales

Reconsidered. Journal of the Folklore Institute 11(3): 147-186.

Barcikowska, A. 2004. Kombinowanie (available online: http://tinyurl.com/zczq513) 
Basso, E. 1988. The Trickster's Scattered Self. Anthropological Linguistics 30(3): 292-318.

Belmonte, T. 1979. The Broken Fountain. New York, NY: Columbia University Press.

Brandth, B. 1995. Rural masculinity in transition: Gender images in tractor advertisements. Journal of Rural Studies 11(2): 123-133.

Certeau, M. de. 1984. The Practice of Everyday Life. Berkeley, CA: University of California Press.

Cooley, T. 2005. Making Music in the Polish Tatras: Tourists, Ethnographers, and Mountain Musicians. Bloomington, IN.: Indiana University Press.

Cybulski, P. 2013. Polityka tłuczonych termometrów. "Polski rząd coraz chętniej (...) zaczyna paskudnie kombinować przy przepisach, by tylko poprawić wyniki i statystyki" (available online: http://wpolityce.pl/polityka/162014-polityka-tluczonych-termometrow-polski-rzad-corazchetniej-zaczyna-paskudnie-kombinowac-przy-przepisach-by-tylko-poprawic-wyniki-i-statystyki)

Dunn, E. 2004. Privatizing Poland: Baby Food, Big Business, and the Remaking of Labour. Ithaca, NY: Cornell University Press.

Fernandez, J. 1972. Persuasions and Performances: Of the Beast in Every Body.....And the Metaphors of Everyman. Daedalus 101 (1), 39-60.

Fernandez, J. 1986. Persuasions and Performances: The play of tropes in culture. Bloomington, IN: Indiana University Press.

Galbraith, M. 1997. "A Pole Can Die for the Fatherland, but Can't Live for Her": Democratization and the Polish Heroic Ideal. Anthropology of East Europe Review 15(2): 119139. 
Galbraith, M. 2003. Gifts and Favors: Social Networks and Reciprocal Exchange in Poland. Ethnologia Europaea 33 (1), 73-94.

Gorlach, K. 1991. Between State and Market: Changing Agriculture in Postcommunist Poland. Jagiellonian University: Program on Central Eastern Europe Working Paper Series \# 29.

Gupta, A. 2005. Narratives of corruption. Anthropological and fictional accounts of the Indian state. Ethnography 6(1): 5-34.

Hann, C. 1985. A Village Without Solidarity: Polish peasants in years of crisis. New Haven, CT: Yale University Press.

Herzfeld, M. 1985. The Poetics of Manhood: Contest and Identity in a Cretan Mountain Village. Princeton, NJ: Pinceton University Press.

Herzfeld, M. 2004. The Body Impolitic. Artisans and Artifice in the Global Hierarchy of Value. Chicago, IL: Chicago University Press.

Holmes, D. 1989. Cultural Disenchantments: Worker Peasantries in Northeast Italy. Princeton: Princeton University Press.

Kennedy, M and I. Białecki. 1989. Power and the Logic of Distribution in Poland. Eastern European Politics and Societies 3(2): 300-328.

Kiereś, M. 2010. Koronka Koniakowska. Istebna: Gminny Ośrodek Kultury - Biblioteka Publiczna w Istebnej.

Kiereś, M. 2012. Ojcowizna koniakowskich górali. Wybrane zagadenia historycno-etnografizncne 300-letniej historii beskidzkiej wsi. Koniaków: Galeria Kukuczka.

Kroh, A. 1999. Sklep potrzeb kulturanych. Warsawa: Prószyński i S-ka 
Kusiak, J. 2012. The Cunning of Chaos and its Orders: A Taxonomy of Urban Chaos in PostSocialist Warsaw and Beyond. In Chasing Warsaw. Socio-Material Dynamics of Urban Change since 1990, M Gubbauer and J.Kusiak (eds), 291-320. Frankfurt and New York: Campus Press.

Ledeneva, A. 1998. Russia's Economy of Favours. Cambridge: Cambridge University Press.

Levi-Strauss, C. 1966. The Savage Mind. Chicago: University of Chicago Press.

Makovicky, N. 2017. The 'Shadows' of Informality in Rural Poland. In Economies of Favour after Socialism, D Henig and N Makovicky (eds), 203-224. Oxford: Oxford University Press.

Manouelian, E. 2000. Invented Traditions: Primitivist Narrative and Design in the Polish Fin de Siècle. Slavic Review 59(2): 391-405.

Malewska-Szalygin, A. 2006. The Polish Political Scene as Seen from a Small Town Market. Anthropology Matters 8(1): 1-8.

Malewska-Szalygin, A. 2008. Wyobrażenia państwie i władzy we wsiach nowotarskich 19992005, Warszawa: DiG.

Marterka, E. 2018. Kombinowanie. Global Encyclopaedia of Informality. London: UCL Press.

Mazurek, M. 2012. Keeping it Close to Home: Resourcefulness and Scarcity in Late Socialist and Postsocialist Poland. In Communism Unwrapped. Consumption in Cold War Eastern Europe, P. Bren and M. Neuberger (eds), 298-323. Oxford: University of Oxford Press.

Morris, J. and A. Polese (eds.). 2013. The Informal Post-Socialist Economy: Embedded practices and livelihoods. London and New York: Routledge.

Morris, J and A. Polese (eds.). 2015. Informal Economies in Post-Socialist Spaces Practices, Institutions and Networks. London and New York: Routledge.

Nagengast, C. 1982. Polish peasants and the state. Dialectical Anthropology 7(1): 47-66. 
Onet. 2011. Studia uczą kombinowania (available online:

http://waszymzdaniem.blog.onet.pl/2011/09/27/studia-ucza-kombinowania/)

Pawlik, W. (ed). 1992. Intimate Commerce. In The Unplanned Society: Poland during and after Communism, J. Wedel (ed), 78-94. New York, NY: Columbia University Press.

Pine, F. 1987. Kinship, Marriage and Social Change in a Polish Highland Village, University of London, Phd thesis, 1987, 1.

Pine, F. 1996. Naming the house and naming the land: kinship and social groups in the Polish highlands. Journal of the Royal Anthropological Institute 2(3): 443-459.

Pine, F. 1997. Pilfering Identity: Górale culture in post-socialist Poland. Paragraph. A Journal of Modern Critical Theory 20(1): 59-74.

Pine, F. 2002. Dealing with money: zlotys, dollars and other currencies in Postsocialist Poland. In Markets and Moralities: Ethnographies of Postsocialism, R. Mandel and C. Humphrey, 77-97. London: Berg (Bloomsbury).

Pine, F. 2007. Dangerous modernities: innovative technologies and the unsettling of agriculture in rural Poland. Critique of Anthropology 27(2), 183-201.

Polese, A. 2008. If I Receive It, It Is a Gift; If I Demand It, It Is a Bribe: On the Local Meaning of Economic Transactions in Post-Soviet Ukraine'. Anthropology in Action, 15(3), 47-60.

Reed-Danahay, D. 1993. Talking about Resistance: Ethnography and Theory in Rural France. Anthropological Quarterly 66(4): 221-229.

Rivkin-Fish, M. 2005. Women’s Health in Post-Soviet Russia. Bloomington, IN: Indiana University Press. 
Saugeres, L. 2002. Of tractors and men: masculinity, technology and power in a French farming community. Sociologia Ruralis 42(2): 143-159.

Scott, J. 1990. Domination and the Arts of Resistance: Hidden Transcripts. New Haven: Yale University Press.

Skapski, L. 2009. Machines. Kraków: Foundation of Visual Arts.

Stoke, J. 2010. The Return of Kaptain Kombinować (available online:

https://polandian.wordpress.com/2010/05/17/kaptain-kombinowac-strikes-again/)

Strathern, M. 1988. The Gender of the Gift. Problems with Women and Problems with Society in Melanesia. Berkeley: University of California Press.

Wanner, K. 2005. Money, Morality and New Forms of Exchange in Ukraine'. Ethnos, 71(4), $515-37$.

Wedel, J. 1986. The Private Poland. An Anthropologist's Look at Everyday Life. New York: Facts on File.

Wedel, J. 1998. Collision and Collusion. The Strange Case of Western Aid to Eastern Europe, 1989-1998. New York: St. Martin’s Press.

Williams, C., J. Round and P. Rodgers. 2013. The Role of Informal Economies in the PostSoviet World: The End of Transition? London and New York: Routledge. 
